\title{
Challenges of Vehicle Parking in Central Business District of SabzevarCity, Iran
}

\author{
Ehsan Amini ${ }^{\# 1}$, Shankar B ${ }^{* 2}$ \\ \#. Research Scholar in Urban and Regional Planning, \\ School of Planning and Architecture, University of Mysore, Mysore, India \\ ehsanamini1983@gmail.com \\ *. Associate Professor, School of Planning and Architecture, University of Mysore, Mysore, India \\ doddi43@gmail.com (Corresponding Author)
}

\begin{abstract}
Central Business Districts (CBDs) are undisputable areas of traffic attraction occasioned by increasing commercial and economic activities. It attracted people from different parts of the city and its region for shopping and recreational facilities and accelerated mobility of vehicles in CBD. The greater mobility has created traffic congestion and parking problems. Due to tremendous increase in vehicular movements in the central areas in recent time, the parking efficiency is affecting people's lifestyle especially during peak hours. The availability of lesser space has been creating great challenges on transport planners for vehicular parking planning and management. Though the Sabzevar's city government has made efforts to solve parking problem in the Central Business District, the parking demand has stroked-up to the unexpected levels. This paper attempts to discuss the parking problems of central business district and proposes measures and strategies for meeting the key challenges of parking demand in the City of Sabzevar.
\end{abstract}

Keywords: Central Business District,Parking, Urban Mobility, Traffic Congestion,

\section{INTRODUCTION}

The parking problem in the city centre emerges from a conflict between demand and supply. Many commercial and public places such as arcades, malls, multiplex systems, hospitals, offices and market areas that are located in CBD, attract people and vehicles but they lack adequate parking facilities. The traffic planners are facing problem in solving the parking problem especially in commercial areas. Finding vacant parking space in the Central Business District (CBD) of the city centre is a time-consuming process. The vehicles which are in search of a parking space rover their vehicles slow, thus congesting the traffic especially during peak hours. The location, design of a car parking can neither easy nor cause traffic congestion most especially within the CBD with a narrow or inadequate road infrastructure [1]. Although on- street parking would be helpful to have easiest accessibility, would reduce the capacity of roads and in such circumstances, on-street parking provokes traffic congestion [2, 3]. Problems of congestions, delays and inadequacies in public transportation have forced people for opting of private vehicles [4]. The private vehicle demands vehicle parking is an essential component of the transportation system. This situation has increased the demand for parking spaces in the Central Business District (CBD) [3]. The vehicle population in Sabzevar has been steadily increasing with the pace picking up significantly since the last 20 years. There has been a rapid increase in automobile dissemination following economic development. The car parking problems and congestion are serious problems and it requires an urgent solution because of the rapid motorization in developing cities like Sabzevar in Iran.

Solving parking problems is a big challenge. The parking policy shall maintain through optimum utilisation of land use over the on- street parking spaces. In central business district of Sabzevar city, it is a common practice that the vehicles are parked along roadsides irregularly and often on both sides cars are parked which reduces the carriage ways. Due to high land value in the central area, the space allocation for parking is low priority resulting in low parking spaces. The parking in the central area of city has been greatly affected by the high mobility in the central area [5]. In the recent years, the Sabzevar municipality in coordination with the government authorities has made some efforts to identify and develop parking areas to overcome the challenges in parking in the central area, but it has been attempted to address the parking problem in a comprehensive manner but it was not much effective as it was expected.

\section{BACKGROUND OF SABZEVAR}

The City of Sabzevar had a population 232000 in 2011 which rose from 30545 in 1956. The city is a capital of Sabzevar County, in Razavi Khorasan Province of north-eastern part of Iran. It is situated approximately 220 kilometres west of Mashhad, the provincial capital and $670 \mathrm{kms}$ from Tehran, the capital of Iran. By considering the antiquity and historical background of Sabzevar, particularly in central parts of city, it has a cultural tissue and the rapid increase in population inversely there is an increase in travel and usage of vehicles, bringing in a lot of vehicle traffic congestion in the Central Business District. The oldest street system of the city is not wide 
enough to support automobile traffic as it was designed 50 years ago for the usage of carts and very few automobiles.

\section{LAND USE PATTERN IN CENTRAL BUSINESS DISTRICT}

The Central Business District (CBD) has an extent of 781000 sq.mts. The residential land use accounts for 46.69 percent followed by 23 percent for traffic network and 15.21 percent for commercial purpose. The rest of the area is accounted for green spaces and open spaces to include sports, cultural and recreational areas. The land use pattern of the CBD during 2010 is depicted in fig. 1 and table 1.

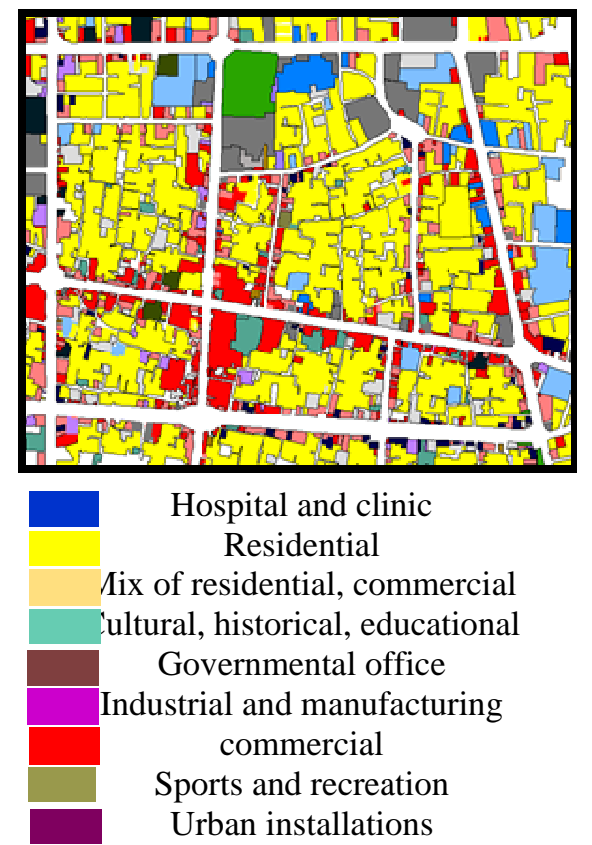

Source: Municipality Report of Subzevar City, 2010

Fig 1. Land Use of Central Business District

TABLE 1. Land Use of Central Business District -2010

\begin{tabular}{|c|c|c|c|}
\hline \multicolumn{2}{|c|}{ Land Use } & Area Sqmts & Percentage \\
\hline \multicolumn{2}{|c|}{ Residential } & 364649 & 46.69 \\
\hline \multicolumn{2}{|c|}{ Commercial, service, private office } & 118790 & 15.21 \\
\hline \multirow{12}{*}{$\begin{array}{l}: 0 \\
\bar{\Xi} \\
\overline{0}\end{array}$} & Educational & \multirow{12}{*}{94501} & \multirow{12}{*}{12.1} \\
\hline & Healthcare & & \\
\hline & Military & & \\
\hline & Sports & & \\
\hline & Administrative & & \\
\hline & Hospitality and Tourism & & \\
\hline & Cultural & & \\
\hline & Historical cultural & & \\
\hline & Religious cultural & & \\
\hline & Warehousing and transportation & & \\
\hline & Urban equipment and facilities & & \\
\hline & Bare land & & \\
\hline \multicolumn{2}{|c|}{ Green space } & 14839 & 1.9 \\
\hline \multicolumn{2}{|c|}{ Industry } & 8591 & 1.1 \\
\hline & Roads and Networks & 179630 & 23 \\
\hline & Total & 781000 & 100 \\
\hline
\end{tabular}

Source: Municipality Report of Subzevar City, 2010 


\section{NUMBER OF VEHICLES REGISTERED IN SABZEVAR CITY}

According to 2013 statistics of City's Police Department, there were 154000 vehicles registered out of which 10,000 were heavy vehicles, 52000 were four wheelers, and 92000 bikes in the city.

TABLE 2. Number of Vehicles Registered in Sabzevar City 2011 to 2013

\begin{tabular}{|l|l|l|l|l|l|}
\hline Year & Four Wheelers & Heavy Vehicle & Motor Cycles & Total & $\begin{array}{l}\text { Annual Growth } \\
\text { Rate (\%) }\end{array}$ \\
\hline 2011 & 30,000 & 6000 & 75,000 & 111,000 & - \\
\hline 2012 & 40,000 & 7000 & 80,000 & 127,000 & 1.145 \\
\hline 2013 & 52,000 & 10,000 & 92,000 & 154,000 & 1.221 \\
\hline
\end{tabular}

Source: City Traffic Police Department, 2013

TABLE 3. Total Volume of Vehicles in Major Streets in CBD 2005 (two-way)

\begin{tabular}{|l|l|l|l|l|}
\hline Busiest Street & Beyhagh St.1 & Kashefi St.2 & Asraar St.4 & Asadaabaadi St.5 \\
\hline Total vehicles & 16931 & 13295 & 11216 & 14217 \\
\hline
\end{tabular}

Source: Municipality Report, 2005

\section{TRAFFIC VOLUME IN CBD}

The volume of traffic has been increasing in the central area. The Beyhagh Street No.1 has accounted for 16931 Passenger Car Unit (PCU) followed by The Asadaabadi Street-5 14217 PCU, The Kashefi Street-2 13295 PCU and The Asraar Street-4 11216 PCU in 2005. These roads were catering to the two-way traffic. The city government has decided to convert all busy roads to one-way since 2009 to reduce vehicular traffic congestions in CBD. The one-way cycle lane includes the Beyhagh Street (St.No.1), the Kashefi Street (St.No.2), Asadaabadi Street (St.No.5) and Asrar Street (St.No.4). For better service to the citizens, there was one-lane special carriage space for public transportation and ambulance (figure 2).

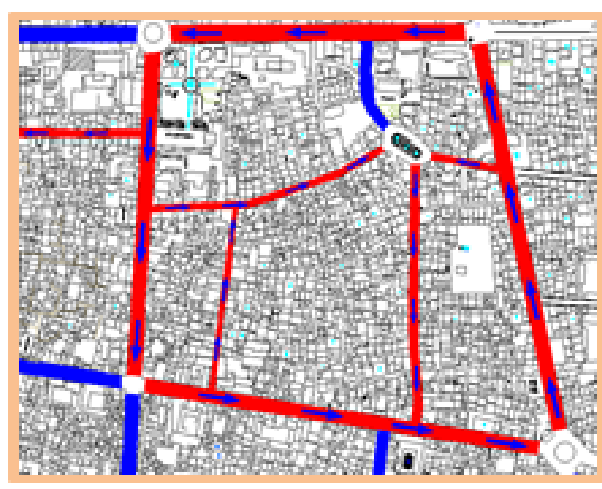

Two way One way

Fig 2. Vehicle Movement Pattern in CBD since 2009

The volume of traffic also reduced on the major roads in CBD and details are given in the fig.3.

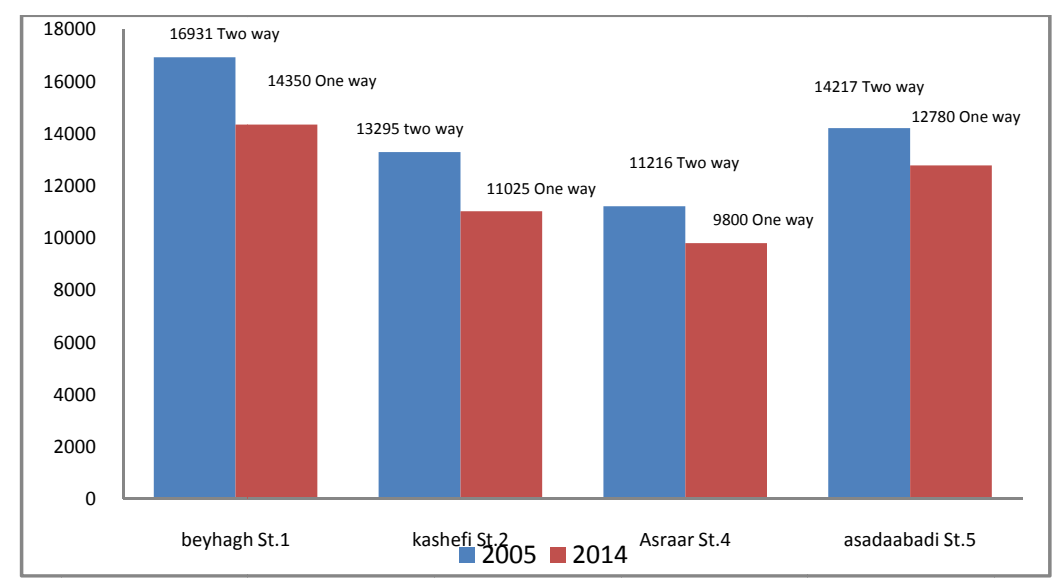

Fig.3. Change in Volume on Major Streets of CBD 


\section{LEVEL OF SERVICES IN CBD}

Level of Service, is a qualitative assessment and it analyses traffic flow based on the speed and density of traffic, travel time and freedom of manoeuvre and also road safety. It also maintains an evaluative determinant of traffic facilitation of the roads. Levels of Service are classified into six categories from A to F. So that level of service A represents the best conditions and level of service $\mathrm{F}$ represents worst traffic conditions[6]. The level of services for different roads in the CBD is depicted in the fig. 4.
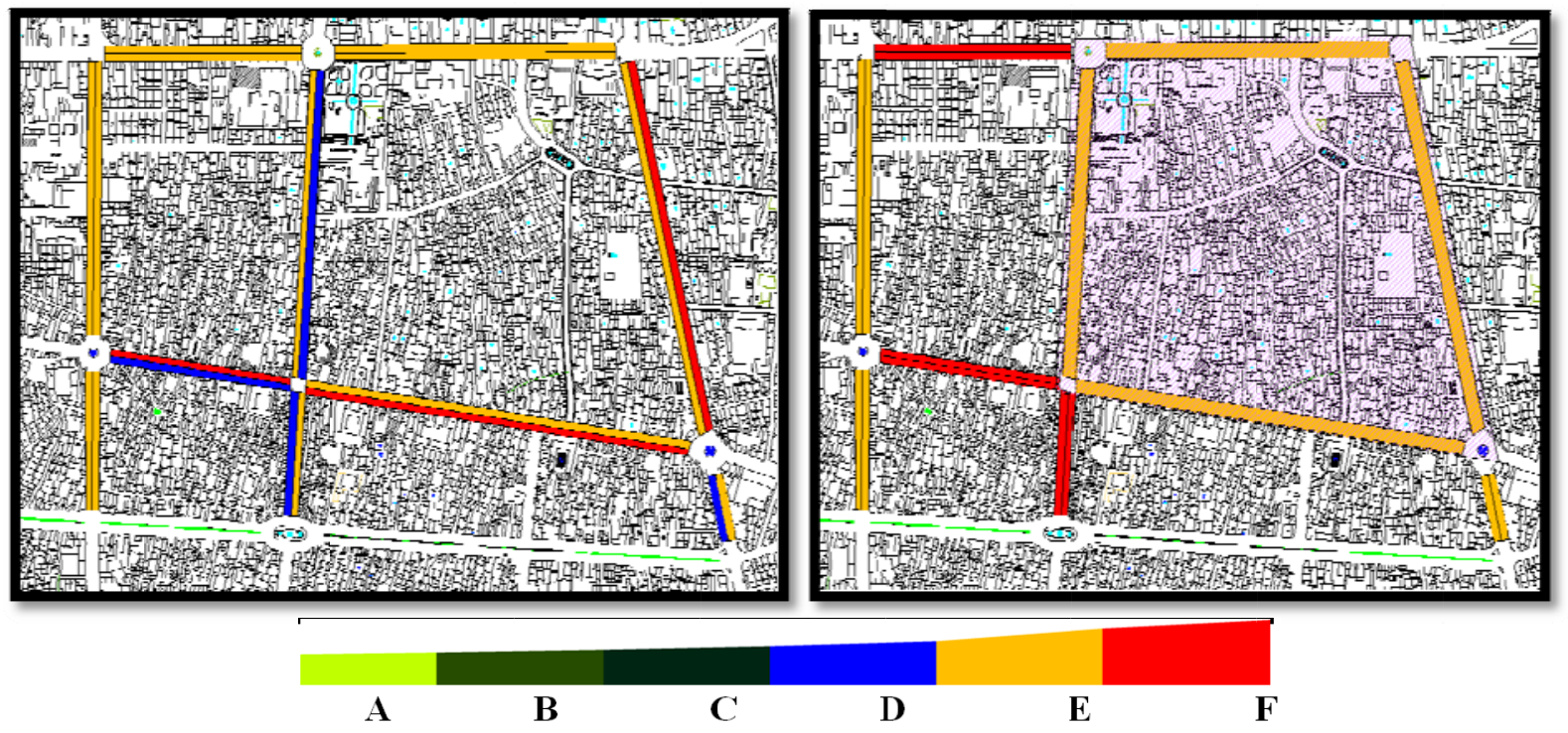

Fig 4. Level of Services in CBD in 2005 and 2010

Note: Volume to Capacity Ration rangeA - 0-0.2; B - 0.2-0.4; C - 0.4-0.6; D - 0.6-0.8; E - 0.8-1.1 and F - >1.1 Source: Municipality Archive Report, 2011

20062014
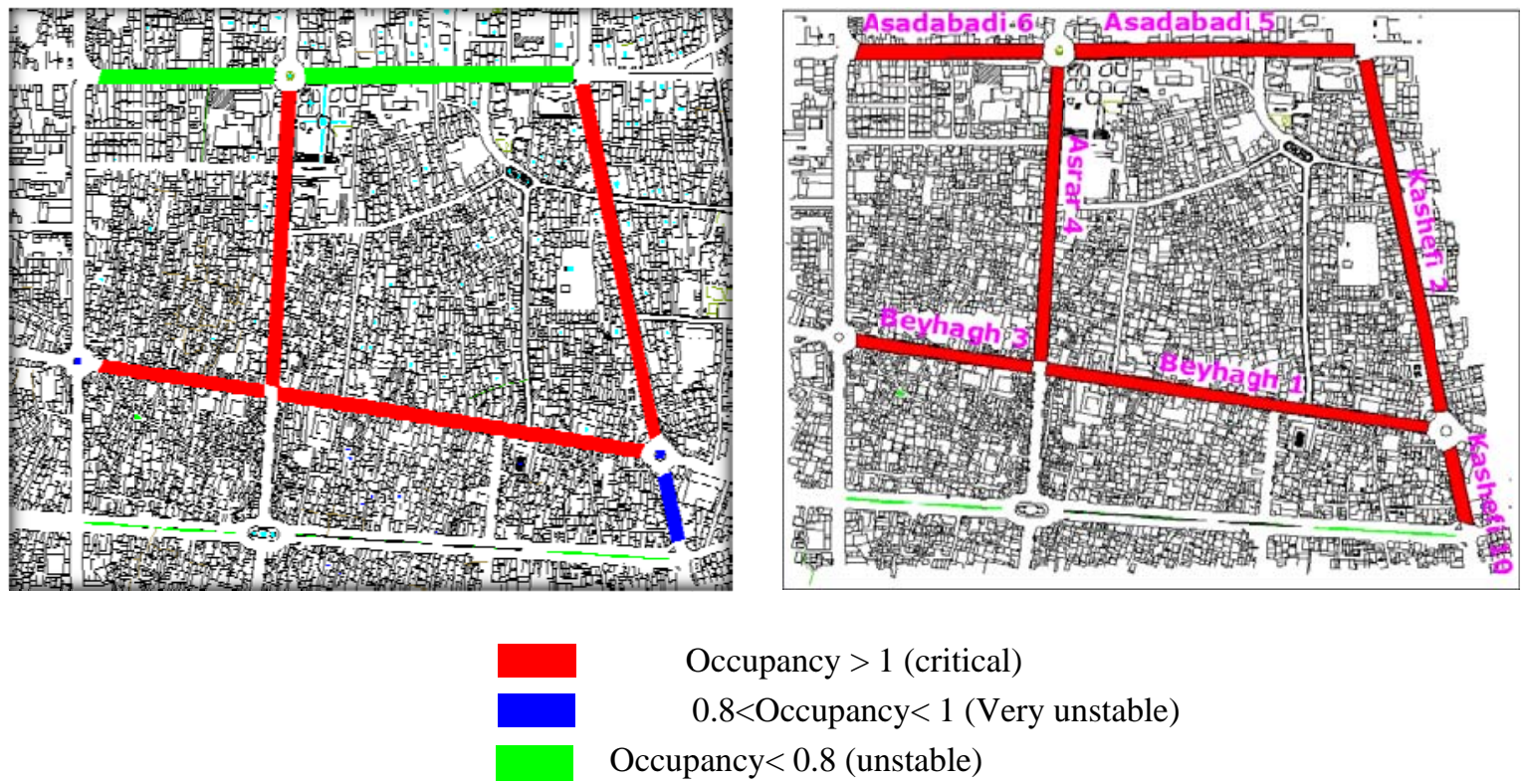

Source: Sabzevar Municipality Report, 2013

Fig5. Occupancy Rate of On-Street Parking in CBD 
According to Master Plan2005, the level of service in west to east direction of Beyhagh Street (Street No.1) and South to North direction of Kashefi Street (Street No.2) were in F condition. Since 2009, a one-way circle in busiest part of CBD was introduced to improve vehicle speed movement. But by considering the changes made in vehicle movement pattern in CBD, level of services in the busiest part a little decreased from 1.27(F) to $1.07 €$ and from $1.38(\mathrm{~F})$ to $1.09 €$. Beyhagh is the oldest street of the city, where the city begins its origins. It is the most important, one way, west - east axis in this region and is not only the main commercial street but also contains numerous heritage architectural monuments as well as the important religious-cultural places. The majority of the oldest structures of Sabzevar city are situated in this street; therefore, it has an old unique architectural character to its location in terms of function and material.

\section{PARKING IN CBD}

In the Central area of the Sabzevar city, the on-street parking is very predominant.Vehicles are parked in state of perpendicular or parallel relating to a low width of carriage way and limited space especially in central business district of Sabzevar city. Existing on-street parking has occupied significant part of roads which results in effective width of carriageway has reduced. The volume has increased in the major roads and this conventional on-street parking system which is typically unsafe, unattractive and is inefficient. Total number of vehicles parked on important roads is depicted in table 4. Accordingly, the Average Occupancy rate in one hour in all roads of CBD, table 5 shows major troubled roads in terms of on-street parking in order of preference.

TABLE 4. Number of Cars Parked in Different Streets

\begin{tabular}{|c|c|c|c|c|c|c|c|}
\hline 总言 & 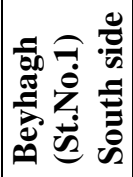 & 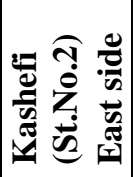 & 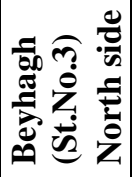 & 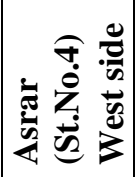 & 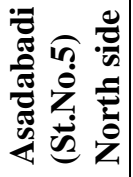 & 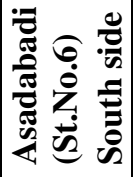 & 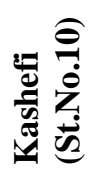 \\
\hline 8 & 80 & 65 & 33 & 90 & 58 & 33 & 31 \\
\hline 9 & 90 & 78 & 33 & 115 & 75 & 37 & 43 \\
\hline 10 & 98 & 90 & 48 & 135 & 99 & 44 & 53 \\
\hline 11 & 105 & 67 & 37 & 138 & 73 & 68 & 45 \\
\hline 12 & 94 & 65 & 25 & 119 & 58 & 45 & 34 \\
\hline 17 & 36 & 36 & 37 & 98 & 85 & 57 & 74 \\
\hline 18 & 33 & 30 & 34 & 103 & 86 & 58 & 70 \\
\hline Avg. & 41.5 & 40.5 & 50.5 & 114 & 92.5 & 78 & 77.5 \\
\hline
\end{tabular}

Source: Primary Survey Conducted by the Author in 2014

TABLE 5. Reduced Functional Capacity of Roads from On-street Parking

\begin{tabular}{|l|l|l|l|}
\hline \multicolumn{1}{|c|}{ Roads name } & $\begin{array}{c}\text { Occupancy } \\
\text { Average }\end{array}$ & $\begin{array}{c}\text { Roadway width } \\
\text { (m) (carriage way } \\
\text { + parking) }\end{array}$ & $\begin{array}{c}\text { Reduced functional } \\
\text { Capacity due to on- } \\
\text { street parking (\%) }\end{array}$ \\
\hline West side of road No.4 & 1.96 & $9(6.5+2.5)$ & 27.77 \\
\hline South side of road No.1 & 1.86 & $9.5(7+2.5)$ & 26.31 \\
\hline South side of road No.6 & 1.76 & $7.28(4.78+2.5)$ & 34.34 \\
\hline East side of road No.2 & 1.41 & $8.6(6.1+2.5)$ & 29.06 \\
\hline North side of roadNo.3 & 1.32 & $6.5(4+2.5)$ & 38.46 \\
\hline North side of roadNo.5 & 1.23 & $12.6(10.1+2.5)$ & 19.84 \\
\hline 2 sides of road No.10 & 1.13 & $13.6(8.6+5)$ & 36.76 \\
\hline
\end{tabular}

Source: Sabzevar Municipality Report, 2013

The important streets namely The Beyhagh Street, The Kashefi Street, The Asrar Street and The Asadabadi Street attract huge volume of vehicles especially during peak hours, but parking facilities which have provided are not able to cater to the increased demand. The widths reserved for on-street parking is depicted in table No.6. 
TABLE 6. Space Occupied for On-Street Parking in CBD

\begin{tabular}{|l|l|}
\hline \multicolumn{1}{|c|}{ Location } & Occupied passages width for parking (m) \\
\hline South side of Beyhagh street (St.No.1) & 2.5 \\
\hline East side of Kashefi street (St.No.2) & 2.5 \\
\hline North side of Beyhagh street (St.No.3) & 2.5 \\
\hline West side of Asrar street (St.No.4) & 2.5 \\
\hline North side of Asadabadi street (St.No.5) & 2.5 \\
\hline Asadabadi street (St.No.6) & 5 \\
\hline East side of Asrar street (St.No.9) & 2.5 \\
\hline Kashefi street (St.No.10) & 5 \\
\hline \multicolumn{2}{|c|}{ Source: SabzevarMunicipality Report }
\end{tabular}

The on-street parking is causing greater problem for road users due to reduction of effective width of carriageway viz. Reduced width of carriage way, uneasy manoeuvres and reduction in speed of vehicles.

TABLE 7. Average Occupancy of On-Street Car Parking

\begin{tabular}{|c|c|c|c|c|c|c|c|}
\hline Time (hour) & 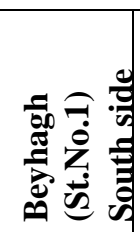 & 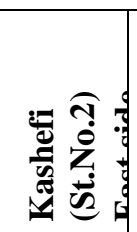 & 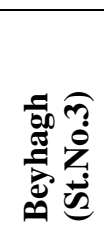 & 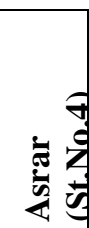 & 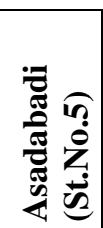 & 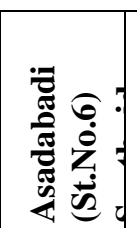 & 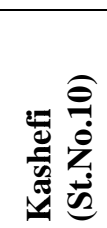 \\
\hline $\begin{array}{l}\text { No. of on-street } \\
\text { parking maneuver } \\
\text { in hour }\end{array}$ & 93 & 78 & 41 & 114 & 80 & 53 & 42 \\
\hline $\begin{array}{l}\text { Average of parked } \\
\text { time (min) }\end{array}$ & 91 & 84 & 87 & 87 & 56 & 75 & 88 \\
\hline $\begin{array}{l}\text { No of side } \\
\text { parking space }\end{array}$ & 50 & 55 & 31 & 58 & 65 & 30 & 37 \\
\hline $\begin{array}{l}\text { Average of } \\
\text { occupancy in hour }\end{array}$ & 1.86 & 1.41 & 1.32 & $\begin{array}{l}1.9 \\
6\end{array}$ & 1.23 & 1.76 & 1.13 \\
\hline
\end{tabular}

Source: SabzevarMunicipality, Report, 2013

The average occupancy per hour is the highest on AsrarStreet No. 4, followed by 1.86 on Beyhagh Street No.1and the lowest occupancy rate was noticed in Kashefi Street No.10. The occupancy rate more than one is considered to be more critical.

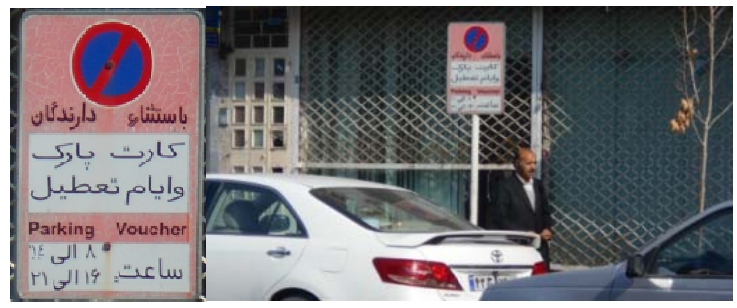

Fig 6. Parking Voucher in CBD Streets

In order to achieve better parking spaces in the central part of city, a parking card system was introduced in the CBD area during peak hours from 8 am to $2 \mathrm{pm}$ and $4 \mathrm{pm}$ to 9 pm except during holidays. Itwas piloted in 3-4 main streets initially and later it was extended to all arterial roads and subsidiary roads of CBD. But, despite the implementation of the plan, still there was a serious parking problem in the central part of city. Thus, the card system was not much effective as it was anticipated and it was not able to meet the parking demands holistically in the CBD because of increasing number of commercial activities followed by increased volume of traffic in all important roads in CBD. 


\section{OFF-STREET PARKING}

There are two official off-street parking areas, one at the northern side and it is situated very close to the municipality. The other site off-street parking is situated at south-eastern part of the Grand Mosque. Apart from two official off-street parking, there are 6 institutions that have parking facilities in their premises though there are about 90 governmental departments, banks, institutions which are located in the central area of city, and only four of them have parking facilities for their employees.

On-street parking

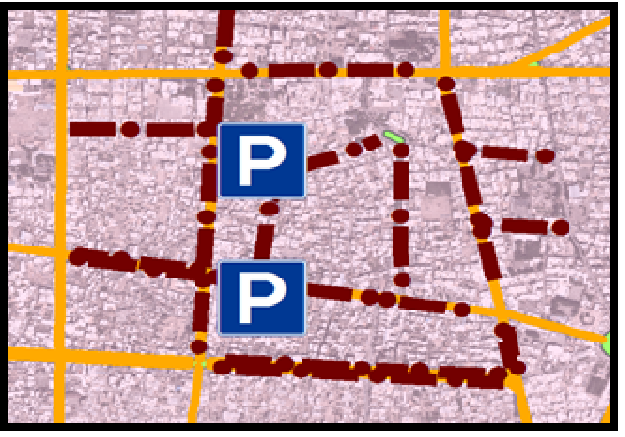

Off-Street-Parking $\mathbf{P}$

Fig7. Off-Street and Off-Street Parking in CBD

TABLE 6. Institutional Parking in CBD

\begin{tabular}{|l|l|l|l|l|}
\hline Sl. No & Location & Parking name & $\begin{array}{l}\text { Parking Area } \\
\text { (sqm) }\end{array}$ & $\begin{array}{l}\text { Number of } \\
\text { Parking Spaces }\end{array}$ \\
\hline $\mathbf{1}$ & $\begin{array}{l}\text { Asrar Street } \\
\text { (St.No.4) }\end{array}$ & $\begin{array}{l}\text { Municipality } \\
\text { (Main office) }\end{array}$ & 1200 & 48 \\
\hline $\mathbf{2}$ & $\begin{array}{l}\text { Asrar Street } \\
\text { (St.No.4) }\end{array}$ & Melli bank & 1100 & 44 \\
\hline $\mathbf{3}$ & $\begin{array}{l}\text { Beyhagh Street } \\
\text { (St.No.1) }\end{array}$ & Main post office & 730 & 30 \\
\hline $\mathbf{4}$ & $\begin{array}{l}\text { Beyhagh Street } \\
\text { (St.No.1) }\end{array}$ & Saderat bank & 500 & 20 \\
\hline $\mathbf{5}$ & $\begin{array}{l}\text { Asadabadi Street } \\
\text { (St.No.5) }\end{array}$ & Keshavarzi bank & 500 & 20 \\
\hline $\mathbf{6}$ & $\begin{array}{l}\text { Asadabadi Street } \\
\text { (St.No.5) }\end{array}$ & $\begin{array}{l}\text { Municipality } \\
\text { (zone 1) }\end{array}$ & 1250 & 50 \\
\hline
\end{tabular}

Source: Field Survey, 2013

\section{PARKING REGULATIONS}

The Master Plan of Subzevar City 2005 has recommended for provision of parking spaces in commercial and administrative complexes and the details are as follows:

- Commercial complexes, commercial centers, malls and etc.: 100 Sq.mts

- Administrative and governmental area: 50 Sq.mts

- Religious area: 30 Sq.mts

Though there is a mandatory requirement for reserving at-least 25 sq.mts in every commercial unit, the above parking regulations have not been implemented effectively to meet the parking demand in the CBD. The guidelines for multilevel car parking are as following:

TABLE 7. Standard Coverage of MLCP

\begin{tabular}{|l|l|}
\hline Type of use & Appropriative distance \\
\hline Commercial and services & $100 \mathrm{~m}-350 \mathrm{~m}$ \\
\hline Administrative & $150 \mathrm{~m}-300 \mathrm{~m}$ \\
\hline Other (Therapeutic, Pilgrimage, Training and etc.) & $200 \mathrm{~m}-350 \mathrm{~m}$ \\
\hline
\end{tabular}




\section{PARKING PROBLEMS IN CBD}
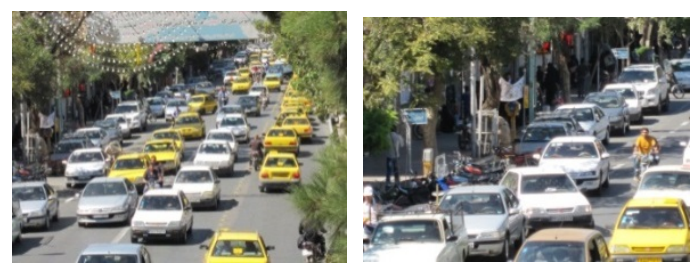

Fig 8. Traffic Congestion

Kashefi is a one-way street carrying the traffic load entering from Beyhagh and south. It is a south-north axis with majority land use of commercial, public and semi-public and multi-functional mixed land uses. Unlike Beyhaghs and Kashefi`s land use and functionality is not limited to only commercial use, but also it has many numbers of health centres, clinics, banks, schools and offices.
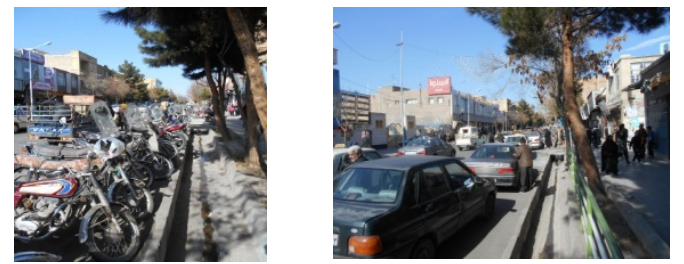

Fig 9.Parking in Early Morning

On the other hand, commercial units with one floor are changing to commercial buildings (complex) without providing parking. These commercial units' parking demand is to be addressed by the local authority in the nearby areas.
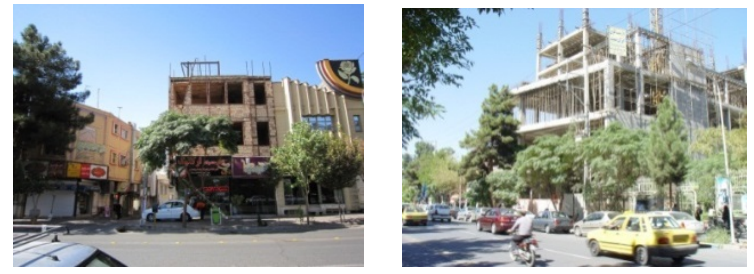

Fig.10 Construction of Commercial Complex without Parking Facilities

The increase in number of on-street parking in CBD of Sabzevar city, roadways capacity has decreased putting a growth line in the traffic congestion, delay and cost of trips and bringing non-designated off-street parking at different unauthorized and indiscriminate parking along the street. Side streets and alleys within the CBD of Sabzevar city have also created a serious barrier to smooth urban mobility and is an indicative of inadequacy management and policy enforcement in the aspects of transport.

The major parking problems that arefacing by the central area are as follow:

a) Long duration parking which is generally done by shop owners and their employees

b) Land owners have converted the parking spaces for other purposes, despite the building regulations which specify a minimum provision of parking area,

c) Parking on both sides of road which reduces mobility of vehicles

d) Parking on No-Parking Zones

e) Parking on Private lands 


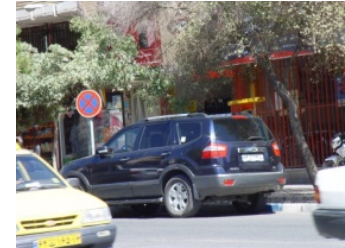

On-street parking on No-parking zone

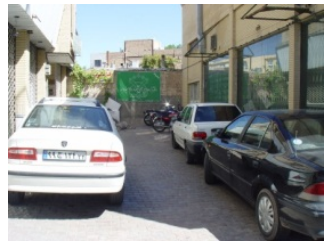

Roads are blocked by Vehicles

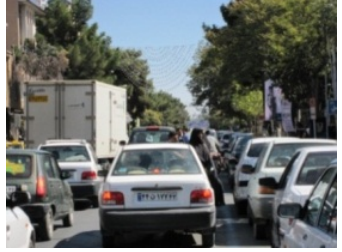

Double on-street parking,

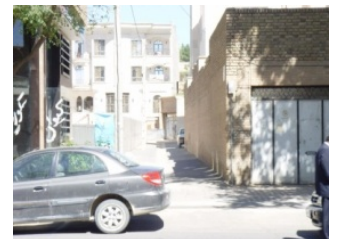

Blocking sidewalks at entrance of Alley

Fig 11. Examples of parking problems

\section{KEY ISSUES AND CHALLENGES OF PARKING}

In Sabzevar city, there is an existent conventional parking system, which is typically unsafe, unattractive and is inefficient. Here vehicles are parked in state of perpendicular or parallel relating to low width of carriage way and limited space especially in central business district of Sabzevar city, in comparison to multi-level car parking (MLCP) systems, traditional parking system is a far less attractive option for urban managers.

Another mode, which could be realized efficiently in such cases, is the automated multi-level car parking system, an efficient system which can handle the same amount of cars in half of as much as the space. Automated parking system can be used for administrative department to provide employees parking requirement in any place of city. Experiences have shown that automated parking system compared with traditional parking system is more economical, space efficient, safe and secure.

\section{A. Strategies:}

With the increasing vehicle ownership, the demand for parking lots has become inevitable in the CBD. Due to the recognition of central business district as heritage zone coupled with increasing land value in the city centre, the widening of the streets for contemplating parking spaces is a less choice of the local self-government. The following strategies are recommended to address the parking problems.

- Promotion of public transportation, created organized public transportation in CBD, especially for one-way cycle which is the busiest part of CBD. It provides better service to citizens, reduces waiting time, encourages people to use public transportation and reduces the tendency to use personal vehicle. The car parking demand shall reduce thereon.

- Changing the CBD area into an integrated grid to Public Transport service.

- Investigating the potential for city to use this strategy (integrated public transportation) in policy development aimed at increasing the Public Transportation modal share and reducing congestion during peak times.

- Parking Fee may be levied and both on-street and off-street parking. Long hours parking to be discouraged and heavy parking fee for long hour parking to be levied.

- Constructing multi-level car parking (MLCP) at the busiest entries of CBD. A multi-level car parking system is meant to maximize car parking capacity by utilizing vertical rather than horizontal space. Multilevel car parking system can be underground, above ground or both under and above ground. Positioning and multilevel parking construction has an important role in reducing the traffic, saving of fuel, reducing air pollution, the process in accelerating and an act of easing in urban transportation. The locations for multilevel parking could preferably on government lands.

\section{CONCLUSIONS}

The parking demand in the central business district of Sabzevar is increasing and the level of services available is reducing for growing demand of parking. In order to meet the challenges various parking demand, measures namely integrated grid transport and public transport service, leaving of fee and multi-level car parking system which is alternative to conventional parking are to be planned and implemented for addressing the parking problem in the Central Business District of Sabzevar City. 


\section{REFERENCES}

[1] Jean-Paul Rodrigue, Urban Transport Challenges, the geography of transport systems, https://people.hofstra.edu/geotrans/eng/ch6en/conc6en/ch6c4en.html

[2] Anumita Roychowdhury, 2012, Parking: Multi-level dilemma, Lessons from Multi-Level Parking in Delhi, right to clean air campaign, Centre for science and environment, New Delhi, http://www.cseindia.org/userfiles/Sarojini_Nagar_Parking_Report.pdf,

[3] Nidhi Mehta, Khatri Pallavi V and Prof. Jayesh Juremalani, 2015, Review of Parking Problems in CBD Area of Urban Cities in Developing Countries, IJIRST, International Journal for Innovative Research in Science \& Technology| Volume 1 | Issue 12 | May 2015,

[4] Dr Wen Long Yue, 2004, Parking management in Saudi Arabia: Is there any solution?, 27th Australasian Transport Research Forum, Adelaide, 29 September - 1 October 2004, Transport Systems Centre, University of South Australia

[5] Seyedeh Zohreh Ahmadi, 2007, Study the problems of parking management and its effect on city traffic, Mashhad,

[6] Sabzevar City Municipality Reports, 2014

[7] Iran statictical center

[8] Dr. Mansoor Haji Hoseinloo, Esmaeil Balal, 2011, Impact of On-street Parking on Main Streets Traffic, Khajeh Nasir University,

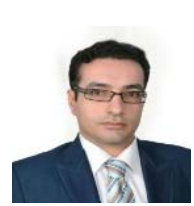

\section{AUTHORS PROFILE}

Ehsan Amini, received Bachelor of Civil Engineering degree from Azad University, Iran in 2008, M. Tech. degree in Urban and Regional Planning from Institute of Development Studies, University of Mysore, India in 2012. Presently, working Ph.D. Research Scholar in Urban \& Regional Planning in School of Planning and Architecture, University of Mysore, Mysore.

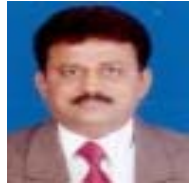

B. Shankar received the B.E. degree in Civil Engineering in 1984, M.U.R.P degree in Urban and Regional Planning in 1989 and Ph.D. degree in Urban and Regional Planning in 1997 from the University of Mysore, Mysore. He is working as Associate Professor in Urban and Regional Planning at the Institute of Development Studies, University of Mysore, Mysore. His research interests include Urban Planning, Spatial and Land Use and Transport Planning, Community Development, Heritage Conservation, and Planning Legislation. 